\title{
Reviews and syntheses: Greenhouse gas exchange data from drained organic forest soils - a review of current approaches and recommendations for future research
}

\author{
Jyrki Jauhiainen $^{1,2}$, Jukka Alm ${ }^{3}$, Brynhildur Bjarnadottir ${ }^{4}$, Ingeborg Callesen ${ }^{5}$, Jesper R. Christiansen ${ }^{5}$, \\ Nicholas Clarke $^{6}$, Lise Dalsgaard ${ }^{7}$, Hongxing He $^{8}$, Sabine Jordan ${ }^{9}$, Vaiva Kazanavičiūtè ${ }^{10}$, Leif Klemedtsson ${ }^{11}$, \\ Ari Lauren $^{3}$, Andis Lazdins ${ }^{12}$, Aleksi Lehtonen ${ }^{1}$, Annalea Lohila ${ }^{13,14}$, Ainars Lupikis ${ }^{12}$, Ülo Mander $^{15}$, \\ Kari Minkkinen $^{2}$, Åsa Kasimir ${ }^{11}$, Mats Olsson ${ }^{9}$, Paavo Ojanen ${ }^{2}$, Hlynur Óskarsson ${ }^{16}$, Bjarni D. Sigurdsson ${ }^{16}$, \\ Gunnhild Søgaard $^{7}$, Kaido Soosaar ${ }^{15}$, Lars Vesterdal ${ }^{5}$, and Raija Laiho ${ }^{1}$ \\ ${ }^{1}$ Natural Resources Institute Finland (Luke), P.O. Box 2, 00791 Helsinki, Finland \\ ${ }^{2}$ Department of Forest Sciences, University of Helsinki, P.O. Box 27, 00014 Helsinki, Finland \\ ${ }^{3}$ Natural Resources Institute Finland (Luke), 80100 Joensuu, Finland \\ ${ }^{4}$ Department of Education, University of Akureyri, 600 Akureyri, Iceland \\ ${ }^{5}$ Department of Geosciences and Natural Resource Management, University of Copenhagen, 1958 Frederiksberg C, Denmark \\ ${ }^{6}$ Department of Terrestrial Ecology, Norwegian Institute of Bioeconomy Research (NIBIO), P.O. Box 115, 1431 Ås, Norway \\ ${ }^{7}$ Department of Forest and Climate, Norwegian Institute of Bioeconomy Research (NIBIO), P.O. Box 115, 1431 Ås, Norway \\ ${ }^{8}$ Department of Biological and Environmental Sciences, University of Gothenburg, P.O. Box 461, 40530 Gothenburg, Sweden \\ ${ }^{9}$ Department of Soil and Environment, Swedish University of Agricultural Sciences, P.O. Box 7014, 75007 Uppsala, Sweden \\ ${ }^{10}$ Department of Environmental Sciences, Vytautas Magnus university, 44248 Kaunas, Lithuania \\ ${ }^{11}$ Department of Earth Sciences, University of Gothenburg, P.O. Box 460, 40530 Gothenburg, Sweden \\ ${ }^{12}$ Latvian State Forest Research Institute (Silava), Salaspils, 2169, Latvia \\ ${ }^{13}$ INAR Institute for Atmospheric and Earth System Research/Physics, Faculty of Science, University of Helsinki, \\ P.O. Box 68, 00014 Helsinki, Finland \\ ${ }^{14}$ Finnish Meteorological Institute, Climate System Research, P.O. Box 503, 00101 Helsinki, Finland \\ ${ }^{15}$ Department of Geography, University of Tartu, 51014 Tartu, Estonia \\ ${ }^{16}$ Agricultural University of Iceland, 311 Hvanneyri, Borgarnes, Iceland
}

Correspondence: Jyrki Jauhiainen (jyrki.jauhiainen@helsinki.fi)

Received: 1 July 2019 - Discussion started: 26 July 2019

Revised: 31 October 2019 - Accepted: 6 November 2019 - Published: 10 December 2019

\begin{abstract}
Drained organic forest soils in boreal and temperate climate zones are believed to be significant sources of the greenhouse gases (GHGs) carbon dioxide $\left(\mathrm{CO}_{2}\right)$, methane $\left(\mathrm{CH}_{4}\right)$ and nitrous oxide $\left(\mathrm{N}_{2} \mathrm{O}\right)$, but the annual fluxes are still highly uncertain. Drained organic soils exemplify systems where many studies are still carried out with relatively small resources, several methodologies and manually operated systems, which further involve different options for the detailed design of the measurement and data analysis protocols for deriving the annual flux. It would be beneficial to set certain guidelines for how to measure and report the data, so that data from individual studies could also be used in
\end{abstract}

synthesis work based on data collation and modelling. Such synthesis work is necessary for deciphering general patterns and trends related to, e.g., site types, climate, and management, and the development of corresponding emission factors, i.e. estimates of the net annual soil GHG emission and removal, which can be used in GHG inventories. Development of specific emission factors also sets prerequisites for the background or environmental data to be reported in individual studies. We argue that wide applicability greatly increases the value of individual studies. An overall objective of this paper is to support future monitoring campaigns in obtaining high-value data. We analysed peer-reviewed publi- 
cations presenting $\mathrm{CO}_{2}, \mathrm{CH}_{4}$ and $\mathrm{N}_{2} \mathrm{O}$ flux data for drained organic forest soils in boreal and temperate climate zones, focusing on data that have been used, or have the potential to be used, for estimating net annual soil GHG emissions and removals. We evaluated the methods used in data collection and identified major gaps in background or environmental data. Based on these, we formulated recommendations for future research.

\section{Introduction}

Organic soils contribute to the atmospheric greenhouse gas (GHG) concentrations, as they can both remove and emit GHGs, and have globally extensive carbon (C) and nitrogen (N) stores (Post et al., 1982; FAO, 2012; IPCC, 2014; Oertel et al., 2016; Wilson et al., 2016). Organic soils are, especially in the boreal region, commonly peat, derived from plant remains that have accumulated below the high water table (WT) of peat-forming wetlands, peatlands. Below the WT, decomposition is anaerobic and generally slow (e.g. Straková et al., 2012). Peatlands have been widely converted into agricultural and forestry land or used for peat extraction (Joosten, 2010). These land uses typically involve drainage by ditching. Draining of organic soils enhances aerobic decomposition and thus the mobilization of their $\mathrm{C}$ and $\mathrm{N}$ stores (e.g. Post et al., 1985; Kasimir-Klemedtsson et al., 1997; Ernfors et al., 2008; Petrescu et al., 2015; Abdalla et al., 2016; Pärn et al., 2018). Forestry is an extensive land-use type on peatlands in northern Europe, especially in the Nordic and Baltic countries (e.g. Barthelmes et al., 2015). The drained organic forest soils of this region may act as significant sources of GHGs (Barthelmes et al., 2015), and their annual carbon dioxide $\left(\mathrm{CO}_{2}\right)$, methane $\left(\mathrm{CH}_{4}\right)$, and nitrous oxide $\left(\mathrm{N}_{2} \mathrm{O}\right)$ emissions and removals have to be reported in the national GHG inventories.

Currently, both the IPCC (2006) Agriculture, Forestry and Other Land Use (AFOLU) guidelines and the IPCC (2014) Wetlands Supplement may be used for reporting the annual GHG emissions and removals for soils under anthropogenic land uses, such as drained organic forest soils. Area-based emission factors (EFs), describing the net annual soil GHG emissions and removals, have been developed to reflect the impacts of ecosystem type, land management and environmental conditions. Countries may opt for different methodological levels in their GHG reporting, so-called Tier 1 to 3, where Tier 1 is the simplest approach with default EFs of the IPCC. IPCC (2014) introduced the most recent Tier 1 EFs for drained organic soils (Fig. 1). In practice, most countries currently use the Tier 1 EFs for soil emissions and removals by drained organic forest soils. Tier $1 \mathrm{EFs}$ are mean values of annualized net emission and removal estimates compiled from published data, categorized by climatic zones, and for some zones also by wide soil nutrient status classes "poor" and "rich" (IPCC, 2014). Tier 2 and Tier 3 are methods that use country-specific EFs (Tier 2) and repeated forest inventories and/or advanced modelling (Tier 3), which should make the national estimates more accurate.

Uncertainty of the estimated emissions is still generally high. For instance, the $95 \%$ confidence interval for the Tier $1 \mathrm{CO}_{2}-\mathrm{C} \mathrm{EF}$ for boreal nutrient-poor soils ranges from $-0.23 \mathrm{tCO}_{2}-\mathrm{C} \mathrm{ha}^{-1} \mathrm{yr}^{-1}$ removal to $0.73 \mathrm{tCO}_{2}-\mathrm{C} \mathrm{ha}^{-1} \mathrm{yr}^{-1}$ emission, and that for the corresponding $\mathrm{CH}_{4} \mathrm{EF}$ ranges from 2.9 to $11 \mathrm{t} \mathrm{CH}_{4} \mathrm{ha}^{-1} \mathrm{yr}^{-1}$ emission (IPCC, 2014). Even in Finland where a Tier 2 method is used, the relative uncertainty of $\mathrm{CO}_{2}$ emissions from organic soils in the reporting category "forest remaining forest" is as high as $150 \%$ (Statistics Finland, 2019). This means that those soils can be either sinks or sources of $\mathrm{CO}_{2}$, though the latter is more likely due to the estimated $1.1 \mathrm{MtC}$ decrease annually in the soil $\mathrm{C}$ stock of those lands. The high uncertainty underlines the need for improvement of GHG emission and removal estimation in countries with a high proportion of drained organic forest soils.

Both data collection and method development for reporting the anthropogenic emissions from drained organic soils have duly received increasing attention, with the aim to improve the accuracy of the emission estimates (e.g. IPCC, 2014; Oertel et al., 2016; Tubiello et al., 2016; Kasimir et al., 2018). The accuracy of EFs can be improved as more peerreviewed data become available and quantify a wider set of specific management options and ecological conditions for a given country or region (e.g. Couwenberg, 2011). However, GHG emission data may be collected with several methodologies, which further involve different options for the detailed design of the measurement and data analysis protocols. Development of more specific EFs also sets prerequisites for the background or environmental data to be reported along with the GHG emission estimates. Since collecting representative GHG emission data is time-consuming and thus costly, it would be beneficial to set certain guidelines for how to report the data and related environmental information, so that each individual study would also contribute to more general analyses based on data collation and modelling, or at least simple regression analyses on the factors potentially influencing the emissions. Yet, so far there has been no systematic assessment on how such data are presented in individual studies or how to improve the applicability of the data collected in individual studies in synthesis work aiming to develop more specific EFs. While there is a growing number of long-term GHG-measuring stations with standardized protocols (e.g. https://www.icos-ri.eu/, last access: 4 December 2019), and a vision towards a more integrated approach (Kulmala, 2018), drained organic soils exemplify systems where many studies are still carried out with relatively small resources and manually operated systems. An overall objective of this paper is to assist the measurers-to-be of such campaigns to plan their data collection and presentation proto- 


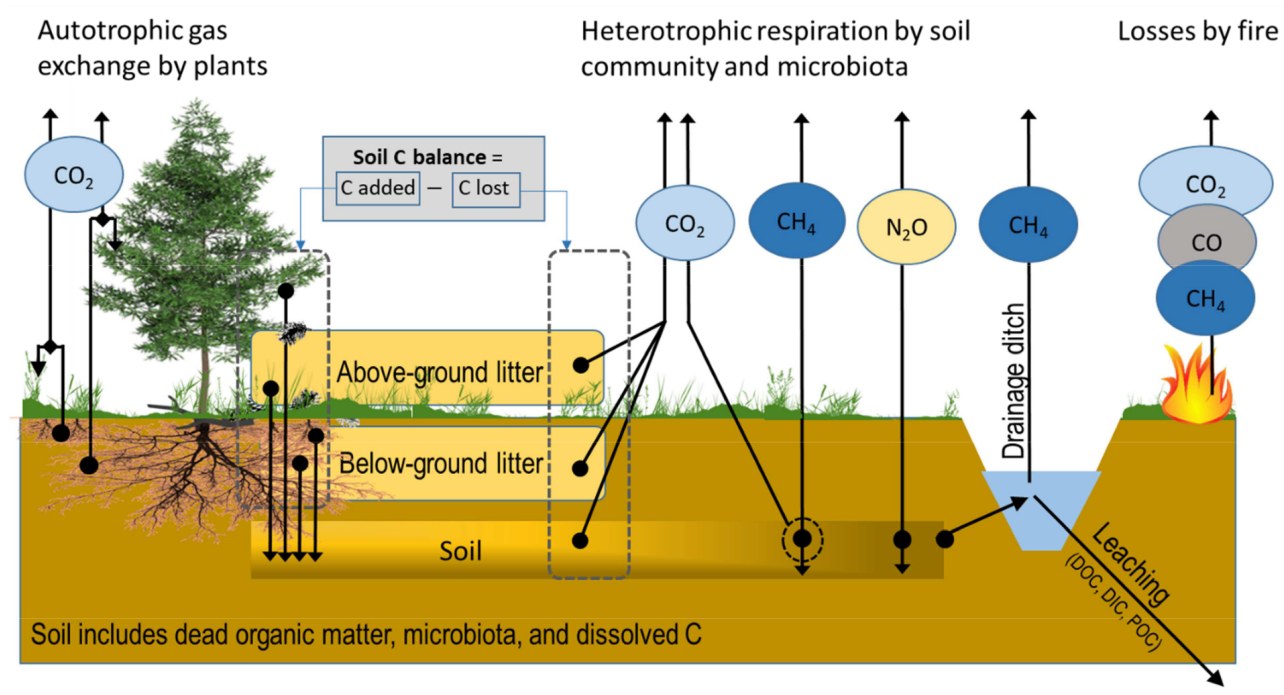

Figure 1. $\mathrm{CO}_{2}, \mathrm{CH}_{4}$ and $\mathrm{N}_{2} \mathrm{O}$ fluxes and mass transfer components contributing to soil $\mathrm{C}$-stock changes in a forest ecosystem on drained organic soil, as in IPCC (2014). Arrows indicate flux/transfer direction.

cols, for enhancing the applicability of their data and thus getting the most out of their hard work.

We analysed peer-reviewed publications presenting GHG data for drained organic forest soils in boreal and temperate climate zones. We focused on data that have been used, or have the potential to be used, for estimating the net annual soil GHG emissions and removals for the measured sites. Such data can then be further used for constructing EFs. The emphasis was on emissions and removals of $\mathrm{CO}_{2}, \mathrm{CH}_{4}$ and $\mathrm{N}_{2} \mathrm{O}$ derived from biological processes taking place between vegetation, soil and the atmosphere on-site. We will henceforward call such annual emission and removal estimates the "soil GHG balance(s)". We set as our aims to (i) collate a database that may be used for developing EFs and (ii) examine the following:

- the data collection methods and data structure in the peer-reviewed publications potentially qualified for estimation of annual soil GHG balances,

- how the characteristics and applicability of the data produced by different GHG monitoring methods differ,

- which type of background data (e.g. tree stand and site characteristics) is provided in the publications that could be used for generalizations and soil GHG balance modelling, and

- which information would be needed for the publications to provide improved applicability for generalizations and modelling.

Because of higher complexity in processes and monitoring approaches for the $\mathrm{CO}_{2}$ flux, we will review $\mathrm{CO}_{2}$ data in more detail than the other gases. Fire-induced emissions will not be dealt with. Waterborne $\mathrm{C}$ losses will be assessed to a limited extent only, due to the scarcity of available data for drained organic forest soils and a recent review published on the subject (Evans et al., 2016).

\section{Material of the review}

We searched peer-reviewed original studies on soil GHG exchange or C-stock changes in drained organic forest soils. The IPCC (2014) Wetlands Supplement reference list contains most of the GHG flux data published until 2013 and was used as a basis that was complemented using reference databases, Web of Science and Google Scholar. Many of the publications are also included in the global soil respiration database, which is open for adding and using published soil respiration data for various ecosystems, including wetlands (Bond-Lamberty and Thompson, 2010; https: //github.com/bpbond/srdb, last access: 4 December 2019).

From the retrieved peer-reviewed publications, we included in the database data that fulfilled the following specifications:

- Data were for forest soils. We followed IPCC (2014), where the minimum criteria are $10 \%$ canopy coverage and 0.5 ha continuous forest area (as in FAO's FRA, 2015). To qualify as forest, the time passed since afforestation had to be over 20 years for sites previously under some other land use. The sites should have been under conventional management conditions, and thus sites with extreme experimental fertilization or hydrology manipulation were excluded. If the publication mentioned tree presence but did not provide sufficient information to confirm that the above forest criteria were met, the data were excluded. 
- Data were for organic soils. As criteria for "organic soil" we followed Annex 3A.5 in IPCC (2006). This means thickness of the organic horizon greater than or equal to $10 \mathrm{~cm}$ and a minimum of $12 \%$ organic $\mathrm{C}$ by mass. In practice this includes both C-rich Histosols (peat) and soils typically identified as Gleysols, which have characteristically lower $\mathrm{C}$ content than peat. If the publication did not specify the soil type or characteristics in an unambiguous manner, the data were excluded.

- Data were for drained organic soils. Data were excluded if it was not specified that the studied site was drained or drainage-impacted.

- Data were from the boreal or temperate climate zone as defined in IPCC (2006), and the monitoring/sampling location was detectable by coordinates.

We formed a database (Supplement Sect. S1, Tables S1 and S2) that includes publications released prior to year 2018 with data on (i) inventories integrating changes in soil $\mathrm{C}$ stocks and (ii) $\mathrm{CO}_{2}, \mathrm{CH}_{4}$ and/or $\mathrm{N}_{2} \mathrm{O}$ fluxes monitored by (a) a chamber technique or (b) an eddy covariance (EC) technique. The few existing peer-reviewed soil $\mathrm{CO}_{2}$ balance estimates based on EC data were assumed to be technically correct. This does not imply that the EC method could be considered perfect as such (e.g. Wang et al., 2017). In data derived by chamber methods, we paid attention to the (i) specification of the flux components monitored (i.e. total vs. autotrophic, ground vegetation presence or removal, inclusion of fluxes from the litter inputs above and below ground), (ii) temporal coverage to facilitate forming an annual estimate, (iii) spatial coverage at the monitoring site, and (iv) description of the methods in flux analysis. For soil inventory methods, we evaluated the ability of the chosen field-work method to provide representative samples with unambiguous references for determining the C-stock change over time. Further, to support constructing EFs and modelling of GHG emissions, the available information on site characteristics, either qualitative or quantitative, was evaluated. Such information includes, for example, temperature sum, site type (at least rich/poor), soil properties, WT regime, description of the forest stocking, tree species composition, and for afforested sites the time of afforestation and previous land use.

\section{Processes and structural features to be covered by monitoring}

Quantifying the soil GHG balance, especially for $\mathrm{CO}_{2}$, in forests growing on organic soils is technically challenging. Monitoring needs to take into account that (i) $\mathrm{C}$ sequestration into plant biomass takes place in a voluminous and usually diverse vegetation community with uneven spatial distribution; (ii) the $\mathrm{C}$ transfer from biomass into dead organic matter as diverse litter forms takes place both above ground and be- low ground with uneven spatial distribution, with the belowground transfers being especially challenging to quantify; (iii) physical and biochemical characteristics in organic soils change over time; (iv) $\mathrm{CO}_{2}$ release through heterotrophic processes takes place both in recently deposited litter and in a soil composed of previously accumulated dead organic matter; (v) in gaseous flux measurements, $\mathrm{CO}_{2}$ formed in the heterotrophic processes in soil must be separated from similarly large $\mathrm{CO}_{2}$ emissions formed in autotrophic root respiration; and (vi) rates of biological processes change over the year and differ between years depending on weather conditions, stand development and management (Fig. 1). In this paper "soil $\mathrm{CO}_{2}$ balance" includes $\mathrm{C}$ transfer fluxes to the soil as above-ground and below-ground litter and losses by decomposition of litter and soil organic matter.

The methods used to quantify soil $\mathrm{CO}_{2}$ balance can be classified into gaseous flux monitoring methods and soil inventory methods. The two method groups differ profoundly in the way they quantify the components of the soil $\mathrm{C}$ balance. Multiple monitoring set-ups are available in both methods, which may influence the estimate formed. This should be considered carefully when planning the measurements, because monitoring set-ups in most studies are chosen to provide data for answering specific research questions, and they do not always aim to quantify the annual soil $\mathrm{CO}_{2}$ balance. A more detailed description of the methods, with their advantages, weaknesses and caveats, is given in the Supplement (Sect. S2). The flux methods include (i) EC flux monitoring by sensors located above the canopy and (ii) chamber techniques involving chambers enclosing a known gas space over soil with or without ground vegetation, litter and roots. Data processing in flux-based methods usually requires additional data on mass-based C-stock changes, such as $\mathrm{C}$ inputs as litter, or change in vegetation $\mathrm{C}$ stock. The soil inventory methods integrate the outcome from all processes affecting the soil C stock over time. C in mass-based C-stock change is converted to $\mathrm{CO}_{2}$ by multiplying with 3.67 (the mass ratio between $\mathrm{CO}_{2}$ and $\mathrm{C}, 44 / 12$ ).

For forming the EFs for $\mathrm{CH}_{4}$ and $\mathrm{N}_{2} \mathrm{O}$ there is no guidance on how living vegetation presence or litter dynamics should be taken into account in flux measurements, except that vegetation presence can be reported for $\mathrm{CH}_{4}$ monitoring locations (IPCC, 2014). However, wetland plants that have roots with aerenchymatous tissue are known to pipe out $\mathrm{CH}_{4}$ from waterlogged peat layers (Askaer et al., 2011). One of such plants is cottongrass (Eriophorum vaginatum), a widespread sedge that is found also on drained sites (e.g. Kokkonen et al., 2019). Excluding these plant types may lead to severe underestimation of the $\mathrm{CH}_{4}$ flux (Askaer et al., 2011). However, in drained sites sedges may also attenuate the emissions (Strack et al., 2006). Further, methanotrophic symbionts dwelling in hyaline cells of Sphagnum mosses are able to oxidize $\mathrm{CH}_{4}$ in solutes to $\mathrm{CO}_{2}$ that is consumed in photosynthesis (Raghoebarsing et al., 2005; Larmola et al., 2010). So far, such observations are available for undrained 
peatlands only. There are also reports indicating that stem bark and leaves are able to transport $\mathrm{N}_{2} \mathrm{O}$ and $\mathrm{CH}_{4}$ from soil to the atmosphere in trees such as black alder (Alnus glutinosa L.) (e.g. Rusch and Rennenberg, 1998; Gauci et al., 2010; Machacova et al., 2013; Covey and Megonigal, 2019; Welch et al., 2019), but the magnitude of such treemediated pathways is still largely unknown. Furthermore, below-ground biomass disturbance, e.g. rhizosphere and mycorrhizal mycelia removal by trenching, has been shown to result in increased $\mathrm{N}_{2} \mathrm{O}$ flux in drained organic forest soils (Ernfors et al., 2011). We therefore paid attention to vegetation disturbance/removal when reviewing the $\mathrm{CH}_{4}$ and $\mathrm{N}_{2} \mathrm{O}$ studies. It seems clear, however, that in future studies of $\mathrm{CH}_{4}$ and $\mathrm{N}_{2} \mathrm{O}$ vegetation should be kept intact.

When estimating $\mathrm{CH}_{4}$ fluxes, it is important to consider the drainage ditches (Fig. 1). They represent wet areas in a drained landscape and may be local hotspots for emissions from the ditch floor and the water column. $\mathrm{CH}_{4}$ emissions can be released by diffusion through the water body, by ebullition and by gas transport through the vegetation, especially sedges (Frenzel and Rudolph, 1998; Saarnio and Silvola, 1999; Natchimuthu et al., 2017), which need to be considered in monitoring. Tier $1 \mathrm{EFs}$ have been constructed for ditch $\mathrm{CH}_{4}$ emissions in IPCC (2014). Information on the proportion of the drainage ditch network area in the landscape is further needed for estimating the emissions. For further modelling of ditch emissions, information on ditch water levels and flow rates, ditch characteristics, vegetation composition and ditch network maintenance likely have importance.

\section{Availability of published data for soil GHG balance estimation}

We reviewed about 130 papers and finally retrieved 52 studies that reported GHG fluxes or C-stock changes in drained organic forest soils in boreal and temperate zones with potential data for estimating soil GHG balance (Sect. S1). Several studies included more than one GHG species monitored (thus, the total $n$ of publications in Table 1 appears to be higher). Most of the $\mathrm{CO}_{2}$ studies used flux monitoring methods; however, studies using inventory methods covered, on average, more sites (Table 1). Studies on $\mathrm{CO}_{2}$ had the highest total number of sites (133), while $\mathrm{N}_{2} \mathrm{O}$ monitoring studies had the lowest (61).

The number of publications in our database (Table 1), complemented with more recent data, became notably higher than that in the IPCC (2014). Our database is not fully matching with the data included in the IPCC (2014) even concerning older data. This is firstly because some studies (8) in the former were replaced by newer publications using the same field data. Secondly, some publications did not match with our criteria, as described in the section "Material of the review" (Sect. S1, Table S4). We identified each monitored site based on coordinates, site type and other information pro- vided in the publications, which prevented double-counting of sites that were, for example, included in review papers. The number of $\mathrm{N}_{2} \mathrm{O}$ monitoring sites was further reduced by recent error detection for 40 sites (Ojanen et al., 2018).

Common reasons for exclusion of a study were insufficient descriptions of the monitored site and methods, unclear data presentation or the same data found in multiple publications (Sect. S1, Table S4). Information about the soil type, forest characteristics or drainage status are important, and insufficient characterization may prevent a conclusion that the studied site represents drained organic forest soils. Unusual forest management conditions, such as experimentally applied unconventionally high amounts of lime or fertilizers, restrict data inclusion from such monitoring sites.

A somewhat more difficult question is how to deal with data quality. Data quality remains undefined if the design of spatial and temporal extent of soil sampling or flux monitoring, or the analytical procedures in the laboratory, are not clearly described. Whereas the EC method is expected to integrate the $\mathrm{C}$ balance over a large area around the sampling spot, absence of spatial replicates on the heterogeneous forest floor in the chamber and soil inventory methods raises concern regarding the representativeness of the monitoring set-up. Another concern in flux monitoring by chambers can be a low sampling frequency and/or extent over time. Conditions in the environment, e.g. vegetation, soil temperature and WT, change over time and need to be included in monitoring not only during the warm season but also during shifts from/to colder seasons. It becomes also overly challenging to estimate cumulative seasonal or annual fluxes if data are presented as series of daily flux values, daily mean flux values or a range of flux values. Some of the methods are no longer considered to produce reliable results, e.g. soda lime absorption for $\mathrm{CO}_{2}$ flux estimation in field conditions (see Sect. S1, Tables S4, S2). The modest number of EC studies (3) in drained organic forest soils limits comparisons in data features in the method. Recent syntheses on EC flux data collected from various ecosystems worldwide are available in Wang et al. (2017).

\section{Applicability of the published data for soil GHG balance estimation}

\subsection{Carbon dioxide}

\subsubsection{Chamber methods}

Flux data monitored by dark chambers form the largest data set for forests on drained organic soils (Fig. 2, Sect. S1). However, complete soil $\mathrm{CO}_{2}$ balance estimates based primarily on data collected on-site are rare (Ojanen et al., 2010, 2013; Meyer et al., 2013; Uri et al., 2017). Ideally, a setup for forming the soil $\mathrm{CO}_{2}$ balance using dark chamber techniques would include quantification of the heterotrophic 
Table 1. Number of sites and publications estimating annual soil balances of $\mathrm{CO}_{2}, \mathrm{CH}_{4}$ and $\mathrm{N}_{2} \mathrm{O}$ for drained organic forest soils in boreal and temperate zones in this study and in the IPCC (2014) Wetlands Supplement.

\begin{tabular}{llrr|rr}
\hline \multirow{2}{*}{ MHG } & Method & \multicolumn{2}{c|}{ This study } & \multicolumn{2}{c}{ IPCC 2014 $^{\mathrm{a}}$} \\
\cline { 3 - 6 } & & $n$-sites & $n$-publications & $n$-sites & $n$-publications \\
\hline $\mathrm{CO}_{2}$ & Inventory & 45 & 5 & - & - \\
& Flux (chambers) & 85 & 19 & - & - \\
& Flux (eddy covariance) & 3 & 3 & - & - \\
\hline & Total & 133 & 27 & 133 & 13 \\
\hline $\mathrm{CH}_{4}$ & Flux (chambers) & 101 & 32 & 143 & 22 \\
$\mathrm{~N}_{2} \mathrm{O}$ & Flux (chambers) & 61 & 31 & 131 & 20 \\
\hline
\end{tabular}

${ }^{a}$ Data from the IPCC (2014) Wetlands Supplement Tables 2.1, 2.3 and 2.5. ${ }^{\mathrm{b}}$ Some publications include estimates for multiple GHGs.

emission sources (litter and soil) without autotrophic emissions from live plants (Sect. S2). Pavelka et al. (2018) provide broad recommendations for chamber measurements in different terrestrial ecosystems.

Generally, cooler night-time temperatures result in lower emissions (Brændholt et al., 2017). Not accounting for this pattern results in overestimated emissions. Automated gas flux monitoring with short intervals ensures capturing the impact of diurnal soil temperature differences on $\mathrm{CO}_{2}$ emissions. Diurnal $\mathrm{CO}_{2}$ flux monitoring by automated chambers has been deployed in two studies (Ball et al., 2007; Meyer et al., 2013). In manual chamber data, the diurnal temperature differences have been taken into account mostly by applying temperature modelling into fluxes monitored during daytime in the boreal zone studies. However, only $36 \%$ of the temperate zone studies accounted for diurnal temperature differences by collecting flux data also during night periods or by modelling (Sect. S1). Consideration given to soil temperature impacts on GHG fluxes should be a requirement in data collection, processing and reporting in studies using manual GHG flux data collection.

Soil $\mathrm{CO}_{2}$ balance is the balance between $\mathrm{C}$ added in litter inputs and $\mathrm{C}$ lost as $\mathrm{CO}_{2}$ in emissions from litter and soil organic matter decomposition. The most typical data lacking for completion of the soil $\mathrm{CO}_{2}$ balance estimate in the reviewed publications were the annual rate of litterfall (Figs. 1 and 2, Sect. S1, Table S1). Emissions from decomposing litter are included in $\mathrm{CO}_{2}$ flux monitoring by having the deposited litter on the soil surface intact, but even then the rate of litter inputs needs to be measured, or estimated, to complement the balance. In studies where the monitored surfaces are kept clean from litter, the above-ground litter $\mathrm{CO}_{2}$ emission must be estimated separately, which may be laborious and result in bias or error. Extensive studies on annual aboveground litter production and decomposition with impact assessment to soil $\mathrm{CO}_{2}$ balance have been made for the boreal zone in Finland (Ojanen et al., 2013, 2014). Comparable integrated assessments for the temperate region, and for af- forested sites, formerly used for peat mining or as cropland, are still lacking. Species-specific above-ground litter production estimates are available for birch, pine and spruce, if measures quantifying the tree biomass are known (e.g. Repola, 2008, 2009). Considerably less specific data are available on understory litter production (Straková et al., 2010), litter decomposition (Domisch et al., 2000; Tuomi et al., 2010; Straková et al., 2012; Ťupek et al., 2015), and, especially, on below-ground (fine root) litter production and decomposition rates (Laiho et al., 2003, 2014; Finér et al., 2011; Jagodzinski et al., 2016; Bhuiyan et al., 2017). Use of generic values for litterfall and litter decomposition cannot be recommended because these rates are site-type-specific, typically differing between nutrient-poor and nutrient-rich sites, and also depend on growing season length (Straková et al., 2010, 2011, 2012; Ojanen et al., 2013; Lehtonen et al., 2016). For more accurate soil $\mathrm{CO}_{2}$ balance estimates, work towards reduced uncertainty in the inputs and decomposition rates of different litter types under different conditions is needed.

Above- and below-ground autotrophic respiration of vegetation remaining inside the chamber is a $\mathrm{CO}_{2}$ flux source that was often acknowledged but not always quantified in the dark chamber studies (Fig. 2, Sect. S1, Table S1). These fluxes are practically impossible to quantify afterwards and thus should be given consideration when performing the measurements and reporting the results. In some studies the soil surface has been free of ground vegetation either naturally due to shading by tree canopy or kept free by frequent clipping. Living roots of both ground vegetation and trees extending to the monitoring plot may still add autotrophic $\mathrm{CO}_{2}$ emission unless specifically excluded by trenching (Subke et al., 2006). Although an approximately 0.5 proportion between total and autotrophic respiration is a fairly common outcome in studies conducted on both organic and mineral soils (e.g. Bond-Lamberty et al., 2004; Comstedt et al., 2011), use of a literature-based fixed coefficient induces a source of uncertainty with a potentially high impact on the soil $\mathrm{CO}_{2}$ balance estimate. For example, in Uri et al. (2017) the proportion be- 


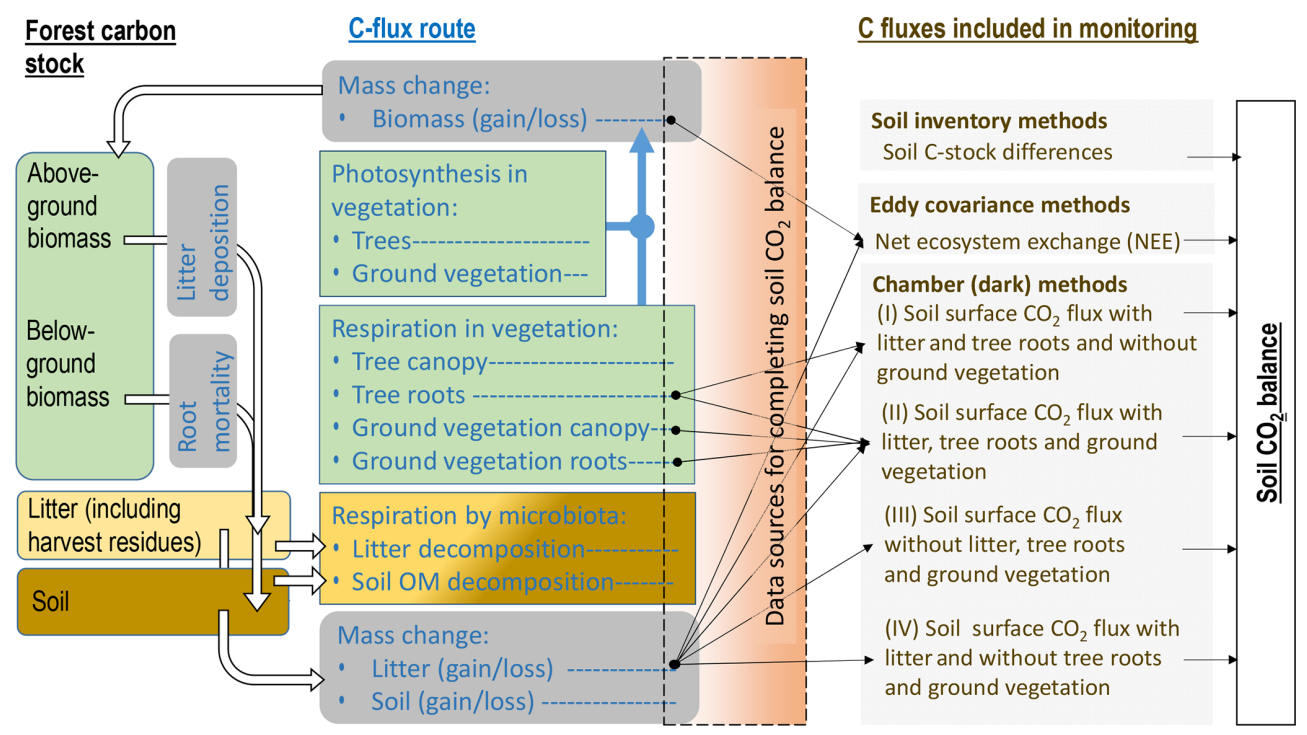

Figure 2. Forest $\mathrm{C}$ stock, processes resulting in changes in the dead organic matter $\mathrm{C}$ stock in soil, $\mathrm{C}$ fluxes typically monitored (see also Sect. S1, Table S1) and complementary data sources needed for forming soil $\mathrm{CO}_{2}$ balance estimates (black arrows) in incomplete flux monitoring set-ups, according to IPCC (2014). Numbers I-IV next to monitoring set-ups by dark chambers refer to respective studies listed in Sect. S1, Table S1. Waterborne C losses and losses by fires are excluded from the figure.

tween heterotrophic and total soil respiration was between 0.6 and 0.7 in five downy birch (Betula pubescens) stands on nutrient-rich drained temperate peatlands. The soil $\mathrm{CO}_{2}$ balances in Uri et al. (2017) would differ on average by $54 \%$ from the reported estimate if the simple 0.5 proportion between the heterotrophic and total soil respiration fluxes were used in the calculation. Data quantifying both total and autotrophic respiration for sites potentially influenced by preceding management impacts, such as afforested former peat mining areas or croplands on organic soils, are currently not available at all.

Modelling, based on on-site flux monitoring, has been done to separate the autotrophic and heterotrophic soil respiration (Ojanen et al., 2010, 2013; Uri et al., 2017). These studies indicated that annual total and heterotrophic respiration both correlate with soil temperatures, but there is substantial between-site variation in the annual fluxes. The share between heterotrophic and autotrophic respiration further varies over the growing season depending on the phenology of trees and understorey vegetation, and this introduces another source of uncertainty in data where heterotrophic emission is proportioned from the monitored total soil $\mathrm{CO}_{2}$ flux. Use of original site-specific heterotrophic emission data integrates local environmental conditions best and should be quantified in flux monitoring. However, it would be useful if general models estimating the proportion between total and autotrophic soil respiration in different types of forests in open, maturing and mature stages; in conditions created by recent management; and with seasonal impacts were further developed.
Several studies monitored $\mathrm{CO}_{2}$ exchange using transparent chambers, but their flux estimates were only rarely suitable for estimating soil $\mathrm{CO}_{2}$ balance in the forest ecosystem. The advantage is the possibility for estimating ground vegetation $\mathrm{C}$ balance. However, a complication of the method in forests is that tree root respiration is also included and difficult to discern from the fluxes. Trenching can be a way to avoid this complexity, but this may also disturb the ground vegetation inside the plot, especially clonal plants for which the rhizomes may extend far beyond the plot limits. That is why this method may produce quite ambiguous results if applied in forests.

\subsubsection{Eddy covariance method}

The eddy covariance (EC) method was applied in three studies (Lohila et al., 2007, 2011; Meyer et al., 2013). The EC method yields the net ecosystem $\mathrm{CO}_{2}$ exchange (NEE) between the ecosystem and the atmosphere, and a set of calculations as well as additional measurements are needed for producing the soil $\mathrm{CO}_{2}$ balance (Sect. S2, Lohila et al., 2007, 2011; Meyer et al., 2013). EC data typically combine high temporal flux sampling intensity with a large areal coverage, i.e. the data have good representativeness for the studied area, and have a relatively small standard error in the NEE estimate (Lohila et al., 2011). For estimating soil $\mathrm{CO}_{2}$ balance as "NEE minus change in vegetation biomass" (Sect. S2), the greatest biomass change in forested sites is naturally in the tree stand. If ground vegetation biomass is low under closed canopy conditions, it can be neglected. The tree biomass change data are usually based on systematic stem 
radial growth and height growth measurements providing cumulative annual data that are combined with biomass allocation models. The errors can be propagated as in Lohila et al. (2011), in which study they were $11.4 \%$ of the mean for NEE and $20 \%$ for annual tree biomass increment. Meyer et al. (2013) compared $\mathrm{CO}_{2}$ balances derived from $\mathrm{EC}$ and automated chamber methods and concluded that the larger accumulated uncertainty for the latter method makes the EC method more reliable. However, the two methods differ by data types and contributing sources of error to an extent that makes it difficult to compare the uncertainties.

\subsection{Inventory methods}

Inventory methods were applied in five studies (Minkkinen and Laine, 1998; Minkkinen et al., 1999; Simola et al., 2012; Pitkänen et al., 2013; Lupikis and Lazdins, 2017). On average, these studies included a higher number of monitored sites compared to studies using flux methods (Table 1). In the largest study, the soil C-stock change estimates of 273 peatland sites were pooled into groups representing three site types for five regions in Finland (Minkkinen and Laine, 1998), while site-specific estimates were given in the other studies. In this method, soil C stocks are estimated at least twice. Volumetric soil samples are taken from the peat surface down to the bottom of the peat deposit. Alternatively, sampling may be extended down to a clearly definable reference layer. The $\mathrm{C}$ stock is calculated from the soil bulk densities and $\mathrm{C}$ concentrations. The stock change is then simply the difference in the $\mathrm{C}$-stock estimates between the time points. Soil $\mathrm{CO}_{2}$ balance estimates based on inventory data integrate the outcome from all C-stock contributing processes over long (decadal) periods. Thus, the method is good for monitoring soil C-stock differences over time in stabilized conditions. The drawback is the difficulty in determining a small temporal change in a very large soil C stock (e.g. Minkkinen and Laine, 1998). Year-to-year differences in soil C stock or specific forms of C or GHGs cannot be studied, which limit the use of the method only for Tier 1 EFs. Reliable estimates may be obtained only if the bottom of the peat deposit is defined accurately and in a similar manner in the repeated sampling, or if an unambiguous reference layer is used that is located deeper in the soil profile than the depth to which anthropogenic changes may be expected to extend (Sect. S2). These conditions cannot usually be met, and thus the inventory methods usually involve very high variation around the estimates. This uncertainty is further contributed to by the spatial variation in peat characteristics and the topography of the bottom of the basin, since exactly the same spots cannot be resampled.

\subsection{Methane and nitrous oxide}

$\mathrm{N}_{2} \mathrm{O}$ and $\mathrm{CH}_{4}$ fluxes have been studied specifically or together with $\mathrm{CO}_{2}$ flux monitoring (Sect. S1, Tables S1 and S2). Most studies (90\%) on $\mathrm{CH}_{4}$ and/or $\mathrm{N}_{2} \mathrm{O}$ fluxes used chambers with retained ground vegetation, if any was present. In three studies vegetation was regularly removed (Danevčič et al., 2010; Ernfors et al., 2011; Holz et al., 2016). In combined $\mathrm{CO}_{2}, \mathrm{CH}_{4}$ and $\mathrm{N}_{2} \mathrm{O}$ monitoring plots, where surface vegetation and litter is removed and/or soil is trenched for studying the heterotrophic $\mathrm{CO}_{2}$ flux, the caused disturbances in vegetation and soil conditions may influence the $\mathrm{CH}_{4}$ and $\mathrm{N}_{2} \mathrm{O}$ fluxes. In Tier 1 EFs by IPCC (2014) only climate, land-use and soil nutrient status information is used.

Presence or absence of plant species that are able to transport $\mathrm{CH}_{4}$ can be accounted for in a Tier 2 method, but there is no specific guidance for how to stratify. For Tier $2 \mathrm{EFs}$, guidance and clarification on how to include ground vegetation, rhizosphere and litter would be useful. For constructing Tier 2 EFs it should be recommended in any case that ground vegetation should be kept intact in $\mathrm{CH}_{4}$ and $\mathrm{N}_{2} \mathrm{O}$ monitoring.

Drained organic forest soils are often small annual sinks of $\mathrm{CH}_{4}$ (Minkkinen et al., 2007; Ojanen et al., 2010). Yet, ditches in such sites may yield significant emissions. A relatively small number of studies have quantified the contribution of drainage ditches to $\mathrm{CH}_{4}$ fluxes in forests (Roulet and Moore, 1995; von Arnold et al., 2005b; Minkkinen and Laine, 2006; Glagolev et al., 2008; Sirin et al., 2012). To our knowledge only Peacock et al. (2017) has measured $\mathrm{N}_{2} \mathrm{O}$ emissions from ditches at semi-natural and cropland sites and found them to be significant. Additional flux data are therefore needed for quantification of this flux in drained forests. To increase applicability, publications on ditch GHG emissions should also provide information on the ditch characteristics, such as size, spacing, current maintenance regime, water level and flow rates during monitoring, and vegetation.

\subsection{Waterborne $\mathrm{C}$}

Both pristine and drained organic soils show $\mathrm{C}$ losses in drainage waters (e.g. Strack et al., 2008; Urbanová et al., 2011; Nieminen et al., 2015). Water draining from organic soils contains dissolved organic C (DOC, typically defined as $\mathrm{C}$ passing through a $0.45 \mu \mathrm{m}$ membrane filter) and particulate organic $\mathrm{C}$ (POC), with the sum of DOC and POC being total organic carbon (TOC). To estimate waterborne $\mathrm{C}$ fluxes, quantification of water flux as well as $\mathrm{C}$ concentrations is necessary. Also, incoming $\mathrm{C}$ in precipitation and influx from surrounding forest soils should be accounted for, when estimating net waterborne $\mathrm{C}$ fluxes. There are several publications reporting the $\mathrm{C}$ concentrations in waters, but complete water flux estimates for a specific forest area/catchment are rare (Sect. S1, Table S3). In practice, the water fluxes are often estimated using models. Current data are too limited for forming explicit views about data applicability. For advancing the knowledge base, it would in any case be useful to include site characteristics and climatic conditions in data collection and reporting. Waterborne $\mathrm{C}$ loss on drained peatlands is included in the review by Evans et al. (2016). 


\subsection{Reporting of key drivers for soil GHG balance}

We currently have the understanding that the GHG fluxes from drained organic forest soils generally depend on site nutrient status, size and characteristics of the tree stand, soil temperature and the WT regime (von Arnold et al., 2005a, b; Ojanen et al., 2010, 2013, 2014). These parameters are not, however, routinely reported in studies quantifying GHG fluxes (Table 2).

In the reviewed data, a surprisingly large proportion of the papers failed to provide information on the basic characteristics of the tree stand (Table 2). Stand volume was the most commonly reported parameter but still only in $50 \%$ of the studies. The tree stand may influence the soil GHG balance in several ways. A large stand volume lowers the WT through canopy interception of precipitation and evapotranspiration (Sarkkola et al., 2010), which may lead to high $\mathrm{CO}_{2}$ emissions and a soil sink of $\mathrm{CH}_{4}$ (Minkkinen et al., 2007; Ojanen et al., 2010). Different tree species produce litters of different quality (e.g. Straková et al., 2010), which decompose at different rates (e.g. Straková et al., 2012) and have been found to result in differing soil GHG fluxes on mineral soils (e.g. Papen and Butterbach-Bahl, 1999; Butterbach-Bahl et al., 2002). Further, tree stand information may be needed for estimating tree litter inputs if those have not been measured.

The volume of increasingly oxic soil above the WT is important for aerobic decomposition processes producing $\mathrm{CO}_{2}$. Also for the balance in processes producing and consuming $\mathrm{CH}_{4}$ in soil, i.e. methanogenesis and methanotrophy, the WT depth influence on oxic and anoxic soil environment is critical. Data provided on WT depth and dynamics were often either lacking, were presented as line graphics only, or were provided for the day of flux monitoring or as average over an arbitrary period. Average annual or seasonal WT were provided in less than half (44\%) of the publications (Table 2). This lack of applicable WT data seriously hampers using this data for meta-analyses and development of more dynamic EFs. Having both mean annual WT and more detailed WT characteristics (e.g. monthly mean and median, quartiles for the growing season, frost-free period and year) in the publication would allow inspection of soil GHG fluxes in specific conditions, such as comparisons between shallow-drained and deep-drained (WT $\leq 30 \mathrm{~cm}$ vs. WT $>30 \mathrm{~cm}$ from the soil surface; IPCC, 2014) conditions.

Less than a third of the publications reported physical (e.g. bulk density) or chemical characteristics (e.g. C, N and $\mathrm{P}$ concentrations; $\mathrm{pH}$ ) of the soil (Table 2). Moreover, differences in the extent of surface soil layers sampled in the studies reduce data comparability. Chemical quality of the organic matter is known to constrain its decomposition rate (e.g. Straková et al., 2012) and the resulting GHG fluxes. Site type, $\mathrm{C} / \mathrm{N}$ ratio and bulk density have been found to correlate with heterotrophic $\mathrm{CO}_{2}$ emission (Ojanen et al., 2010), whereas $\mathrm{N}_{2} \mathrm{O}$ flux increases with lower peat $\mathrm{C} / \mathrm{N}$ ratio (Klemedtsson et al., 2005; Ojanen et al., 2010, 2018;
Pärn et al., 2018). To some extent, this soil quality aspect is taken into account in IPCC (2014) Tier 1 level EFs by using the "nutrient-poor" and "nutrient-rich" site categories. For generalization of GHG fluxes in different site conditions and organic soil types, e.g. by model development, concentrations of the key elements $(\mathrm{C}, \mathrm{N}, \mathrm{P})$ that are part of the decomposition process should preferably be included in reporting. Sampling depth for determining soil characteristics in drained forest soils should be within the vegetation rooting zone and above the WT. A $0-20 \mathrm{~cm}$ soil layer was the most commonly used and would be an easy standard as it does not require very specific sampling tools like deeper coring. Both the rooting zone and the WT are often deeper than this, however, and a specific study might lead to a bettermotivated standard. Also, it should be noted that, on longdrained sites, there may be a thick surface layer accumulated from post-drainage tree litter (e.g. Saarinen and Hotanen, 2000; Straková et al., 2010), corresponding to mineral soil forest $\mathrm{O}$ and $\mathrm{H}$ horizons. Such a layer may be difficult to separate from the actual peat soil (Laiho and Pearson, 2016) but should also better not be separated, since it is also affecting the soil GHG fluxes and balance.

All studies commendably reported the coordinates of the sites. This is important since coordinates unambiguously specify site location and, for example, allow retrieval of climate data.

\subsection{Spatial scale covered with different methods}

The spatial scale varies for methods used for GHG and soil C-stock change monitoring from point measurements (peat cores) in inventory methods to ca. $0.5-1 \mathrm{~m}^{2}$ in plots monitored by chambers, and further to a flux source area (footprint area) of over thousand square metres in the case of EC monitoring. An increase in the number of spatial replicates, i.e. the number of monitoring points, increases the spatial representativeness in both inventory and gaseous flux monitoring by chambers. In the reviewed soil inventory studies, multiplesite surveys included 1-5 sampling points at each site and 1-3 replicate cores at each sampling point. In studies utilizing chamber techniques, on an average there were 8 replicate flux monitoring points per site for $\mathrm{CO}_{2}$ (range 2 to 48 ), 5 for $\mathrm{CH}_{4}$ (2 to 16) and 5 for $\mathrm{N}_{2} \mathrm{O}$ (2 to 16). The size of flux monitoring points varied from $10 \mathrm{~cm}$ diameter areas monitored by cylindrical chambers to $60 \mathrm{~cm} \times 60 \mathrm{~cm}$ areas enclosed by permanently installed frames. It can be reasoned that one EC tower gives an integrated flux for the whole footprint area, while the representativeness in flux estimates based on chambers can be limited if common site vegetation, soil or topography characteristics are not covered by the monitoring points, and/or if the areal proportions of these properties are unknown. On the other hand, the closed chamber technique is the best option for studying GHG fluxes from (small-scale) specific soil surfaces and is often used to complement EC monitoring. In soil inventory methods as well, attention to 
Table 2. Potential GHG flux drivers, and respective information availability for the monitored sites in the reviewed 52 soil GHG flux publications on drained organic forest soils.

\begin{tabular}{|c|c|c|c|}
\hline & Measure & Papers $^{\mathrm{a}}$ & Possible relation in soil GHG fluxes to larger data analysis \\
\hline \multirow{4}{*}{ 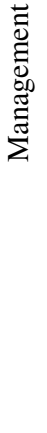 } & Time of site draining & $38(73 \%)$ & $\begin{array}{l}\text { Describes land management duration as (forestry) drained site. May affect } \\
\text { GHG fluxes since length of time during which efficient aerobic decomposi- } \\
\text { tion of surface peat has taken place may affect peat characteristics. }\end{array}$ \\
\hline & Management history described & $52(100 \%)$ & $\begin{array}{l}\text { Draining improvements, fertilization, thinning, selective logging and other } \\
\text { operations conducted in known time periods in the past may have influence } \\
\text { on soil GHG balances. }\end{array}$ \\
\hline & $\begin{array}{l}\text { Ditch spacing and characteristics } \\
\text { described }\end{array}$ & $1(2 \%)$ & $\begin{array}{l}\text { Indicates draining conditions and is useful for assessing ditch GHG emis- } \\
\text { sions. }\end{array}$ \\
\hline & Ditch maintenance condition described & 0 & $\begin{array}{l}\text { Indicates draining conditions and is useful for assessing ditch GHG emis- } \\
\text { sions. }\end{array}$ \\
\hline \multirow{5}{*}{ 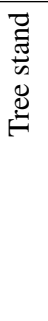 } & Volume & $26(50 \%)$ & \multirow{4}{*}{$\begin{array}{l}\text { Describes forest above-ground C stocking and litter input capacity, corre- } \\
\text { lated with WT through rain interception and evapotranspiration. }\end{array}$} \\
\hline & Basal area & $5(10 \%)$ & \\
\hline & Stem number & $7(13 \%)$ & \\
\hline & Stand age & $16(31 \%)^{\mathrm{b}}$ & \\
\hline & Species composition & $52(100 \%)$ & $\begin{array}{l}\text { Deciduous/conifer dominance or mixed forest structure may produce above- } \\
\text { ground litter types with differing characteristics and thereby influence de- } \\
\text { composition. Different species may also have differing transpiration rates, } \\
\text { affecting WT. }\end{array}$ \\
\hline
\end{tabular}

Productivity $1(2 \%)$

Classification based on expected tree growth potential to "typical" and "low-productivity" sites, where the latter includes sites with characteristically low forest stand stocking and growth due to nutrient deficiency, nutrient imbalance or hydrological conditions (despite draining), and this has impact on soil GHG balances (as in IPCC, 2014).

\begin{tabular}{|c|c|c|c|}
\hline \multirow{12}{*}{ 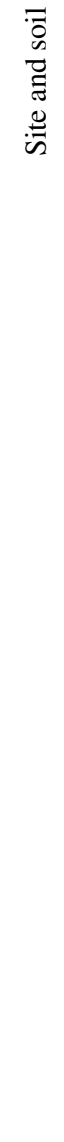 } & Site type ${ }^{\mathrm{d}}$ & $50(96 \%)$ & $\begin{array}{l}\text { Similar sites likely have similarities in GHG dynamics, and it is thus useful } \\
\text { to group sites into similar categories (i.e. by vegetation type or soil nutrient } \\
\text { status etc.). }\end{array}$ \\
\hline & $\begin{array}{l}\text { Ground vegetation composition and } \\
\text { cover }\end{array}$ & $32(62 \%)$ & $\begin{array}{l}\text { Indicator of soil fertility, moisture and shading conditions, and important } \\
\text { for decomposition activity in soil. }\end{array}$ \\
\hline & $\begin{array}{l}\text { Presence and proportions of different } \\
\text { plant functional types in the ground } \\
\text { vegetation }\end{array}$ & $0^{\mathrm{e}}$ & $\begin{array}{l}\text { Simple classification based on ground vegetation dominance by } \\
\text { shrubs/herbs/grasses likely indicates soil nutrient status, thereby pos- } \\
\text { sibly influencing decomposition, and this classification can be practical for } \\
\text { grouping sites into similar categories. }\end{array}$ \\
\hline & $\begin{array}{l}\text { Pre-drainage ombrotrophy or } \\
\text { minerotrophy }\end{array}$ & $52(100 \%)$ & $\begin{array}{l}\text { In general, peats of ombrotrophic and minerotrophic sites differ in soil qual- } \\
\text { ity and decomposition activity. }\end{array}$ \\
\hline & Soil type & $52(100 \%)$ & $\begin{array}{l}\text { Peat and other organic soil types (Gleysols, muck, etc.) differ by formation } \\
\text { and characteristics, which may influence soil GHG balances. }\end{array}$ \\
\hline & Organic soil thickness ${ }^{\mathrm{c}}$ & $29(56 \%)$ & $\begin{array}{l}\text { Shallow organic soil may be impacted by minerogenic waters and mineral } \\
\text { soil underneath and thus have higher decomposition activity than deeper } \\
\text { organic soils. }\end{array}$ \\
\hline & Soil bulk density & $26(60 \%)$ & $\begin{array}{l}\text { High bulk density values may indicate presence of mineral substrates, non- } \\
\text { peat soils and/or possible disturbance in organic soil layer, which may influ- } \\
\text { ence soil GHG balances. Bulk density is also correlated with the degree of } \\
\text { decomposition (e.g. Päivänen, 1969; Silc and Stanek, 1977) and water re- } \\
\text { tention characteristics of the peat (e.g. Weiss et al., 1998), which may affect } \\
\text { the GHG fluxes. }\end{array}$ \\
\hline & $\mathrm{pH}$ & $30(58 \%)$ & Topsoil nutrient status and $\mathrm{pH}$ may influence vegetation composition, rate \\
\hline & $\mathrm{C}$ & $18(35 \%)$ & of $\mathrm{C}$ sequestration by tree stand, litter quality and decomposition rate. Peat \\
\hline & $\mathrm{N}$ & $24(46 \%)$ & layers for which data have been given also vary. A common standard could \\
\hline & $\mathrm{C} / \mathrm{N}$ ratio & $24(46 \%)$ & be a $0-20 \mathrm{~cm}$ layer. \\
\hline & $P$ & $14(27 \%)$ & \\
\hline
\end{tabular}


Table 2. Continued.

\begin{tabular}{|c|c|c|c|}
\hline & Measure & Papers $^{\mathrm{a}}$ & Possible relation in soil GHG fluxes to larger data analysis \\
\hline 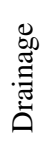 & $\begin{array}{l}\text { Average WT levels in soil: } \\
\text { annual } \\
\text { warm season }^{\mathrm{f}} \\
\text { cold season }^{\mathrm{f}}\end{array}$ & $\begin{array}{l}23(44 \%) \\
4(8 \%) \\
0\end{array}$ & $\begin{array}{l}\text { WT level has major impact on decomposition processes and } \mathrm{CH}_{4} \text { produc- } \\
\text { tion and oxidation rates, and thus basic WT characteristics would be useful } \\
\text { to summarize in numeric form, e.g. monthly mean and median, and also } \\
\text { quartiles for the growing season, frost-free period and year. }\end{array}$ \\
\hline 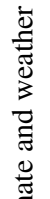 & $\begin{array}{l}\text { Average air temperatures: } \\
\text { annual } \\
\text { July } \\
\text { February } \\
\text { monitoring period }^{\mathrm{f}}\end{array}$ & $\begin{array}{l}34(65 \%) \\
9(17 \%) \\
9(17 \%) \\
0\end{array}$ & $\begin{array}{l}\text { Air temperature has impact on litter production and topsoil decomposition } \\
\text { processes. Inter-annual differences in air temperatures are potentially useful } \\
\text { for modelling and detecting weather extremes during measurements. }\end{array}$ \\
\hline$\stackrel{\Xi}{\Xi}$ & Annual air temperature sum & $7(13 \%)$ & $\begin{array}{l}\text { Describes the temperature climate and annual conditions in a cumulative } \\
\text { manner. }\end{array}$ \\
\hline
\end{tabular}

Average soil temperatures:

annual

monitoring period $^{\mathrm{f}}$
$5(10 \%)$

0

Topsoil temperatures influence especially aerobic decomposition processes and are influenced by diurnal air temperature, and temperatures below the WT influence anaerobic decomposition processes. Measurements at 5 and $30 \mathrm{~cm}$ were most commonly used and could serve as standards.

Precipitation:

annual warm season $^{\mathrm{f}}$ cold season $^{\mathrm{f}}$ Cumulated precipitation may influence decomposition processes in soil (form a proxy for soil wetness or dryness).

0

${ }^{\mathrm{a}}$ Number (and proportion) of papers included in the database that provide the specified information. ${ }^{\mathrm{b}}$ For planted sites time of planting given with precision from year to a decade. ${ }^{c}$ Specific or average values for the monitoring site soil characteristics, not minimum/maximum or a range. ${ }^{\mathrm{d}}$ Site type based on a defined generally applied classification system. ${ }^{\mathrm{e}}$ Not countable from the papers in an unambiguous way for comparisons. ${ }^{f}$ Not countable from the papers in an unambiguous way as the data collection periods were described, for example, as a snow-free period, a warm season or as a period between two dates.

representative sampling at the study site is important. This can, however, not always be realized, as the repeated sampling needs to follow the initial sampling design of the former study in the past, which has typically been designed for other purposes (Minkkinen and Laine, 1998; Simola et al., 2012).

Sampling procedures are strongly constrained by resources and are often trade-offs between spatial and temporal representativeness. It has not been thoroughly investigated so far how the spatial and temporal measurement frequencies affect the precision of the estimated soil GHG balance. Such an analysis would be beneficial for structuring measurements towards better landscape level soil GHG budgets, and such an analysis could be based on, for example, data from sites where both EC and chamber methods have been applied.

\subsection{Temporal scale covered with different methods}

The temporal scale of GHG flux sampling ranges from continuous sampling with EC to automated chamber monitoring at varying frequencies, as well as non-continuous manually performed (daytime) sampling from chambers in intervals of several days to weeks. If GHG flux data collection is continued over several years, the multiple annual soil GHG balance estimates obtained yield a valuable description of the dynamics of the GHG fluxes in varying environmental conditions.

In about half $(53 \%)$ of the flux studies GHG monitoring lasted for at least 2 years, and thus nearly half of the publica- tions included data from 1-year or shorter monitoring. Most studies $(77 \%)$ included also at least some flux monitoring events during cold (winter/frosted soil/snow cover) periods, while a small $(7 \%)$ proportion of the studies were restricted to the warm season. Such seasonal flux data collection periods were described, for example, as a snow-free period or warm season, which does not provide an unambiguous or easy way to extrapolate the results of the monitoring period to the rest of the year. The IPCC (2014) applied an annualization coefficient of 1.15 for the few seasonal GHG flux estimates that excluded the cold period. This coefficient was formed for boreal and subarctic climate regions on the basis of studies in which both warm- and cold-season GHG fluxes were quantified (Dise, 1992; Aurela et al., 2002; Kim et al., 2007; Alm et al., 1999; Leppälä et al., 2011). Use of such a fixed coefficient is a source of uncertainty, since (i) the length of the (un)monitored period may vary from study to study, and (ii) seasonal flux data and data used for forming the coefficient may not come from comparable climatic or site conditions. Although wintertime fluxes form a relatively small proportion of the annual flux (15\% as applied in IPCC, 2014), more year-round field data from a larger number of sites in drained conditions would be beneficial for further modelling of cold-season GHG fluxes. This may be especially critical for regions where the frost-free part of the cold season is lengthening, which may well affect the soil GHG balance. 
Of the three GHGs dealt with, at least $\mathrm{CO}_{2}$ flux correlates even with small changes in the topsoil temperatures (e.g. Brændholt et al., 2017). Thus, flux monitoring should cover the diurnal and annual temperature conditions reliably (Sander and Wassmann, 2014) and ideally should be as continuous as possible over seasons. If automated chamber monitoring is not possible, irregular and diurnally imbalanced GHG flux monitoring data should be corrected using the soiltemperature-GHG-flux relation.

Soil inventory methods, in contrast to flux monitoring methods, integrate all soil $\mathrm{C}$-stock changes $\left(\mathrm{C}\right.$ losses as $\mathrm{CO}_{2}$ and $\mathrm{CH}_{4}$, waterborne $\mathrm{C}$ losses, and new $\mathrm{C}$ accumulation from litter inputs) over time into one soil $\mathrm{CO}_{2}$ balance estimate. Thus, inventory studies done with sufficient spatial coverage and accuracy in determining the boundaries of the studied layer would give the most robust estimates on soil $\mathrm{CO}_{2}$ balance, especially when carried out over a period with no major land-use or environmental changes. When several land-use or management changes have taken place during the time period covered by the repeated sampling, the average soil $\mathrm{CO}_{2}$ balance obtained may not describe any specified condition. Thus, it may be concluded that, generally, estimates obtained by flux methods are better suited for GHG inventories aiming to report current fluxes and their dynamic responses to management. Having said that, GHG flux studies on the impacts of typical management events (e.g. thinning, clear cutting, draining improvements) or covering a complete forest rotation cycle (open, maturing and matured stages) are yet to come.

\section{Summarizing conclusions on data and further data needs}

Basic definitions and guidelines for forming EFs for GHG inventories on organic soils are provided by IPCC (2006, 2014). Datasets used for forming EFs have passed peerreviewing during the publication process and later evaluation by expert teams, but there are no guidelines for the data content and reporting. Consistent data would increase the applicability of the data for forming more specific Tier 2 EFs and in other synthesizing assessments. We have identified issues in data content and reporting that have the potential to further increase applicability of the data for these purposes. Each data collection method and data type has its strengths and weaknesses that contribute to the final outcome when converted to soil GHG balance estimates. It would be highly beneficial to consider post-publication data use already during reporting by providing details on site characteristics and conditions, which are relatively easily acquirable measurements that have the potential to correlate with GHG fluxes (Table 2). We identified major gaps in data and provide some development suggestions for future data collection, as follows:
- Lack of applicable data, mostly due to a lack of environmental data, hampers developing more dynamic EFs than mere averages that currently provide the most basic Tier 1 level for GHG inventories.

- More details on the characteristics and conditions at the monitoring sites (Table 2) are necessary to better analyse and synthesize the general dependencies between the GHG fluxes and environmental parameters.

- Consideration given to diurnal and longer-term soil temperature impacts on monitored GHG fluxes should be a requirement for manual GHG flux data collection by chambers.

- More empirical cold-season GHG flux data are needed for modelling.

- Flux monitoring period restricted to seasonal (warm period) monitoring should preferably be started and ended by defined weather conditions, e.g. soil frost-free period or growing season, which would help in annualization of the results.

- There is a lack of studies relating GHG fluxes and long-term WT regimes (e.g. shallow-drained vs. deepdrained conditions) and of unambiguous water table summaries in GHG flux reporting in general.

- A model needs to be developed for estimating the contribution of autotrophic respiration to the total soil $\mathrm{CO}_{2}$ emissions in different types of forests at different stages of stand development.

- Work toward reduced uncertainty in production and decomposition rates of below-ground litter types, e.g. fine roots, in different conditions is needed because these data are still only sparsely available and typically not quantified in flux studies.

- There is a need for integrated studies on annual aboveground litter production and decomposition with impact assessment to soil $\mathrm{CO}_{2}$ balance for the temperate region and for afforested sites, formerly used for peat mining or as cropland.

- GHG and environmental data collection should cover whole forest rotations, by selecting comparable sites representing different stages of stand development for monitoring.

- The indirect short- or longer-term impact on GHG fluxes of forest management events, such as clear cutting, thinning and ditch network maintenance, should be quantified.

- $\mathrm{CH}_{4}$ and $\mathrm{N}_{2} \mathrm{O}$ fluxes from trees should be quantified for different tree species under different WT regimes. 
- In future studies of $\mathrm{CH}_{4}$ and $\mathrm{N}_{2} \mathrm{O}$ fluxes, vegetation and litter should be kept intact in the flux measurement points.

- $\mathrm{CH}_{4}$ and $\mathrm{N}_{2} \mathrm{O}$ flux data quantifying emissions from drainage ditches are needed for different site types and ditch conditions. Ditch characteristics should be reported for the monitored sites.

- Current waterborne C-flux data are very limited, and thus there is need for data quantifying these $\mathrm{C}$ fluxes from drained organic forest soils.

Data availability. The research data used in this study are peerreviewed publications listed in Supplement Sect. S1. The main data content is provided in Tables $\mathrm{S} 1$ and $\mathrm{S} 2$.

Supplement. The supplement related to this article is available online at: https://doi.org/10.5194/bg-16-4687-2019-supplement.

Author contributions. All authors planned the research jointly and contributed to data collection. JJ retrieved and reviewed the data, compiled the database, wrote the first draft of the manuscript, compiled the Supplement, coordinated the commenting and revisions that were provided by all authors, and compiled the following versions together with RL. KM drafted the description of the inventory method (Sect. S2.1), ALo the description of the EC method (Sect. S2.2) and PO the description of the chamber method (Sect. S2.3), which are presented in the Supplement.

Competing interests. The authors declare that they have no conflict of interest.

Acknowledgements. This research was part of the SNS-120 project "Anthropogenic greenhouse gas emissions from organic forest soils: improved inventories and implications for sustainable management", a spin-off of the CAR-ES network.

Financial support. This research was supported by the Nordic Forest Research SNS (grant nos. SNS-120 and CAR-ES III), with additional support from the University of Helsinki grant to the Peatland Ecology Group; the Academy of Finland (grant no. 289116); the Ministry of Education and Research of Estonia (grant no. PRG-352); the Danish Innovation Fund (FACCE ERA-GAS, grant no. 7108-00003b); and the European Union through the Centre of Excellence EcolChange in Estonia.

Open access funding was provided by the Helsinki University Library.
Review statement. This paper was edited by Kees Jan van Groenigen and reviewed by Ben Bond-Lamberty and Kees Jan van Groenigen.

\section{References}

Abdalla, M., Hastings, A., Truu, J., Espenberg, M., Mander, Ü., and Smith, P.: Emissions of methane from northern peatlands: a review of management impacts and implications for future management options, Ecol. Evol., 6, 7080-7102, https://doi.org/10.1002/ece3.2469, 2016.

Alm, J., Schulman, L., Walden, J., Nykänen, H., Martikainen, P. J., and Silvola, J.: Carbon balance of a boreal bog during a year with an exceptionally dry summer, Ecology, 80, 161-174, https://doi.org/10.2307/176987, 1999.

Askaer, L., Elberling, B., Friborg, T., Jørgensen, C. J., and Hansen, B. U.: Plant-mediated $\mathrm{CH}_{4}$ transport and $\mathrm{C}$ gas dynamics quantified in-situ in a Phalaris arundinacea-dominant wetland, Plant Soil, 343, 287-301, https://doi.org/10.1007/s11104-011-0718-x, 2011.

Aurela, M., Laurila, T., and Tuovinen, J.-P.: Annual $\mathrm{CO}_{2}$ balance of a subarctic fen in northern Europe: Importance of the wintertime efflux, J. Geophys. Res., 107, 4607, https://doi.org/10.1029/2002JD002055, 2002.

Ball, T., Smith, K. A., and Moncriff, J. B.: Effect of stand age on greenhouse gas fluxes from a Sitka spruce [Picea sitchensis (Bong.) Carr.] chronosequence on a peaty gley soil, Glob. Change Biol., 13, 2128-2142, https://doi.org/10.1111/j.13652486.2007.01427.x, 2007.

Barthelmes, A., Couwenberg, J., Risager, M., Tegetmeyer, C., and Joosten, H.: Peatlands and Climate in a Ramsar context: A Nordic-Baltic Perspective, https://doi.org/10.6027/TN2015-544, 2015.

Bhuiyan, M. R., Minkkinen, K., Helmisaari, H.-S., Ojanen, P., Penttilä, T., and Laiho, R.: Estimating fine-root production by tree species and understorey functional groups in two contrasting peatland forests, Plant Soil, 412, 299-316, https://doi.org/10.1007/s11104-016-3070-3, 2017.

Bond-Lamberty, B. and Thomson, A.: A global database of soil respiration data, Biogeosciences, 7, 1915-1926, https://doi.org/10.5194/bg-7-1915-2010, 2010.

Bond-Lamberty, B., Wang, C., and Gower, S. T.: A global relationship between the heterotrophic and autotrophic components of soil respiration?, Glob. Change Biol., 10, 1756-1766, https://doi.org/10.1111/j.1365-2486.2004.00816.x, 2004.

Brændholt, A., Steenberg Larsen, K., Ibrom, A., and Pilegaard, K.: Overestimation of closed-chamber soil $\mathrm{CO}_{2}$ effluxes at low atmospheric turbulence, Biogeosciences, 14, 1603-1616, https://doi.org/10.5194/bg-14-1603-2017, 2017.

Butterbach-Bahl, K., Rothe, A., and H. Papen, H.: Effect of tree distance on $\mathrm{N}_{2} \mathrm{O}$ and $\mathrm{CH}_{4}$-fluxes from soils in temperate forest ecosystems, Plant Soil, 240, 91-103, https://doi.org/10.1023/A:1015828701885, 2002.

Comstedt, D., Boström, B., and Ekblad, A.: Autotrophic and heterotrophic soil respiration in a Norway spruce forest: estimating the root decomposition and soil moisture effects in a trenching experiment, Biogeochemistry, 104, 121-132, https://doi.org/10.1007/s10533-010-9491-9, 2011. 
Couwenberg, J.: Greenhouse gas emissions from managed peat soils: is the IPCC reporting guidance realistic?, Mires Peat, 8, $1-10,2011$.

Covey, K. R. and Megonigal, J. P.: Methane production and emissions in trees and forests, New Phytol., 222, 35-51, https://doi.org/10.1111/nph.15624, 2019.

Danevčič, T., Mandic-Mulec, I., Stres, B., Stopar, D., and Hacin, J.: Emissions of $\mathrm{CO}_{2}, \mathrm{CH}_{4}$ and $\mathrm{N}_{2} \mathrm{O}$ from Southern European peatlands, Soil Biol. Biochem., 42, 1437-1446, https://doi.org/10.1016/j.soilbio.2010.05.004, 2010.

Dise, N. B.: Winter fluxes of methane from Minnesota peatlands. Biogeochemistry, 17, 71-83, https://doi.org/10.1007/BF00002641, 1992.

Domisch, T., Finér, L., Laiho, R., Karsisto, M., and Laine, J.: Decomposition of Scots pine litter and the fate of released carbon in pristine and drained pine mires, Soil Biol. Biochem., 32, 15711580, https://doi.org/10.1016/S0038-0717(00)00070-5, 2000.

Ernfors, M., von Arnold, K., Stendahl, J., Olsson, M., and Klemedtsson, L.: Nitrous oxide emissions from drained organic forest soils - an up-scaling based on $\mathrm{C}: \mathrm{N}$ ratios. Biogeochemistry, 89, 29-41, https://doi.org/10.1007/s10533-008-9190y, 2008.

Ernfors, M., Rütting, T., and Klemedtsson, L.: Increased nitrous oxide emissions from a drained organic forest soil after exclusion of ectomycorrhizal mycelia, Plant Soil, 343, 161-170, https://doi.org/10.1007/s11104-010-0667-9, 2011.

Evans, C. D., Renou-Wilson, F., and Strack, M.: The role of waterborne carbon in the greenhouse gas balance of drained and re-wetted peatlands, Aquat. Sci., 78, 573-590, https://doi.org/10.1007/s00027-015-0447-y, 2016.

FAO: Peatlands - Guidance for climate change mitigation by conservation, rehabilitation and sustainable use, Rome, Food and Agriculture Organization of the United Nations, edited by: Joosten, H., Tapio-Biström, M.-L., Tol, S., available at: http: //www.fao.org/docrep/015/an762e/an762e.pdf (last access: 4 December 2019), 2012.

Finér, L., Ohashi, M., Noguchi, K., and Hirano, Y.: Fine root production and turnover in forest ecosystems in relation to stand and environmental characteristics, Forest Ecol. Manag., 262, 20082023, https://doi.org/10.1016/j.foreco.2011.08.042, 2011.

Frenzel, P. and Rudolph, J.: Methane emission from a wetland plant: the role of $\mathrm{CH}_{4}$ oxidation in Eriophorum, Plant Soil, 202, 27-32, https://doi.org/10.1023/A:1004348929219, 1998.

Gauci, V., Gowing, D. J. G., Hornibrook, E. R. C., Davis, J. M., and Dise, N. B.: Woody stem methane emission in mature wetland alder trees, Atmos. Environ., 44, 2157-2160, https://doi.org/10.1016/j.atmosenv.2010.02.034, 2010.

Glagolev, M. V., Chistotin, M. V., Shnyrev, N. A., and Sirin, A. A.: The emission of carbon dioxide and methane from drained peatlands changed by economic use and from natural mires during the summer-fall period (on example of a region of Tomsk oblast), Agrochemistry, 5, 46-58, 2008.

Holz, M., Aurangojeb, M., Kasimir, Å., Boeckx, P., Kuzyakov, Y., Klemedtsson, L., and Rütting, T.: Gross Nitrogen Dynamics in the Mycorrhizosphere of an Organic Forest Soil, Ecosystems, 19, 284-295, https://doi.org/10.1007/s10021-015-9931-4, 2016.

IPCC: 2006 IPCC Guidelines for National Greenhouse Gas Inventories, prepared by the National Greenhouse Gas Inventories Programme, edited by: Eggleston, H. S., Buendia, L., Miwa,
K., Ngara, T., and Tanabe, K., IGES, Japan, available at: https: //www.ipcc-nggip.iges.or.jp/public/2006gl/ (last access: 4 December 2019), 2006.

IPCC: 2013 Supplement to the 2006 IPCC Guidelines for National Greenhouse Gas Inventories: Wetlands, edited by: Hiraishi, T., Krug, T., Tanabe, K., Srivastava, N., Baasansuren, J., Fukuda, M., and Troxler, T. G., IPCC, Switzerland, 353 pp., available at: https://www.ipcc-nggip.iges.or.jp/public/wetlands/ (last access: 4 December 2019), 2014.

Jagodzinski, A. M., Ziółkowski, J., Warnkowska, A., and Prais, H.: Tree age effects on fine root biomass and morphology over chronosequences of Fagus sylvatica, Quercus robur and Alnus glutinosa stands, PLoS ONE, 11, e0148668, https://doi.org/10.1371/journal.pone.0148668, 2016.

Joosten, H.: The Global Peatland $\mathrm{CO}_{2}$ Picture: Peatland Status and Drainage Related Emissions in All Countries of the World (Wetland International, Ede, The Netherlands), available at: https://www.wetlands.org/publications/ the-global-peatland-co2-picture/ (last access: 4 December 2019), 2010.

Kasimir, A., He, H., Coria, J., and Nordén, A.: Land use of drained peatlands: Greenhouse gas fluxes, plant production, and economics, Glob. Change Biol., 24, 3302-3316, https://doi.org/10.1111/gcb.13931, 2018.

Kasimir-Klemedtsson, ̊̊, Klemedtsson, L., Berglund, K., Martikainen, P., Silvola, J., and Oenema, O.: Greenhouse gas emissions from farmed organic soils: a review, Soil Use Manage., 13, 245-250, https://doi.org/10.1111/j.1475-2743.1997.tb00595.x, 1997.

Kim, Y., Ueyama, M., Nakagawa, F., Tsunogai, U., Harazono, Y., and Tanaka, N.: Assessment of winter fluxes of $\mathrm{CO}_{2}$ and $\mathrm{CH}_{4}$ in boreal forest soils of central Alaska estimated by the profile method and the chamber method: a diagnosis of methane emission and implications for the regional carbon budget, Tellus B, 59, 223-233, https://doi.org/10.1111/j.1600-0889.2006.00233.x, 2007.

Klemedtsson, L., von Arnold, K., Weslien, P., and Gundersen, P.: Soil $\mathrm{CN}$ ratio as a scalar parameter to predict nitrous oxide emissions, Glob. Change Biol., 11, 1142-1147, https://doi.org/10.1111/j.1365-2486.2005.00973.x, 2005.

Kokkonen, N., Laine, A., Laine, J., Vasander, H., Kurki, K., Gong, J., and Tuittila, E.-S.: Responses of peatland vegetation to 15year water level drawdown as mediated by fertility level, J. Veg. Sci., 30, 1206-1216, https://doi.org/10.1111/jvs.12794, 2019.

Kulmala, M.: Build a global Earth observatory. Nature, 553, 21-23, https://doi.org/10.1038/d41586-017-08967-y, 2018.

Laiho, R. and Pearson, M.: Surface peat and its dynamics following drainage - do they facilitate estimation of carbon losses with the C/ash method? Mires Peat, 17, 1-19, https://doi.org/10.19189/MaP.2016.OMB.247, 2016.

Laiho, R., Vasander, H., Penttilä, T., and Laine, J.: Dynamics of plant-mediated organic matter and nutrient cycling following water-level drawdown in boreal peatlands, Global Biogeochem. Cy., 17, 1053, https://doi.org/10.1029/2002GB002015, 2003.

Laiho, R., Bhuiyan, R., Straková, P., Mäkiranta, P., Badorek, T., and Penttilä, T.: Modified ingrowth core method plus infrared calibration models for estimating fine root production in peatlands, Plant Soil, 385, 311-327, https://doi.org/10.1007/s11104014-2225-3, 2014. 
Larmola, T., Tuittila, E.-S., Tiirola, M., Nykänen, H., Martikainen, P. J., Yrjälä, K., Tuomivirta, T., and Fritze, H.: The role of Sphagnum mosses in the methane cycling of a boreal mire, Ecology, 91, 2356-2365, https://doi.org/10.1890/09-1343.1, 2010.

Lehtonen, A., Palviainen, M., Ojanen, P., Kalliokoski, T., Nöjd, P., Kukkola, M., Penttilä, T., Mäkipää, R., Leppälammi-Kujansuu, J., and Helmisaari, H.-S.: Modelling fine root biomass of boreal tree stands using site and stand variables, Forest Ecol. Manag., 359, 361-369, https://doi.org/10.1016/j.foreco.2015.06.023, 2016.

Leppälä, M., Laine, A. M., and Tuittila, E.-S.: Winter carbon losses from a boreal mire succession sequence follow summertime patterns in carbon dynamics, Suo, 62, 1-11, available at: http:// www.suo.fi/pdf/article9874.pdf (last access: 4 December 2019), 2011

Lohila, A., Laurila, T., Aro, L., Aurela, M., Tuovinen, J.-P., Laine, J., Kolari, P., and Minkkinen, K.: Carbon dioxide exchange above a 30-year-old Scots pine plantation established on organicsoil cropland, Boreal Environ. Res., 12, 141-157, available at: http://www.borenv.net/BER/pdfs/ber12/ber12-141.pdf (last access: 4 December 2019), 2007.

Lohila, A., Minkkinen, K., Aurela, M., Tuovinen, J.-P., Penttilä, T., Ojanen, P., and Laurila, T.: Greenhouse gas flux measurements in a forestry-drained peatland indicate a large carbon sink, Biogeosciences, 8, 3203-3218, https://doi.org/10.5194/bg-8-32032011, 2011.

Lupikis, A. and Lazdins, A.: Soil carbon stock changes in transitional mire drained for Forestry in Latvia: a case study, Res. Rural Dev., 1, 55-61, https://doi.org/10.22616/rrd.23.2017.008, 2017.

Machacova, K., Papen, H., Kreuzwieser, J., and Rennenberg, H.: Inundation strongly stimulates nitrous oxide emissions from stems of the upland tree Fagus sylvatica and the riparian tree Alnus glutinosa, Plant Soil, 364, 287-301, https://doi.org/10.1007/s11104-012-1359-4, 2013.

Meyer, A., Tarvainen, L., Nousratpour, A., Björk, R. G., Ernfors, M., Grelle, A., Kasimir Klemedtsson, A., Lindroth, A., Räntfors, M., Rütting, T., Wallin, G., Weslien, P., and Klemedtsson, L.: A fertile peatland forest does not constitute a major greenhouse gas sink, Biogeosciences, 10, 7739-7758, https://doi.org/10.5194/bg-10-7739-2013, 2013.

Minkkinen, K. and Laine, J.: Long-term effect of forest drainage on the peat carbon stores of pine mires in Finland, Can. J. Forest Res., 28, 1267-1275, https://doi.org/10.1139/x98-104, 1998.

Minkkinen, K. and Laine, J.: Vegetation heterogeneity and ditches create spatial variability in methane fluxes from peatlands drained for forestry, Plant Soil, 285, 289-304, https://doi.org/10.1007/s11104-006-9016-4, 2006.

Minkkinen, K., Vasander, H., Jauhiainen, S., Karsisto, M., and Laine, J.: Post-drainage changes in vegetation composition and carbon balance in Lakkasuo mire, Central Finland, Plant Soil, 207, 107-120, https://doi.org/10.1023/A:1004466330076, 1999.

Minkkinen, K., Penttilä, T., and Laine, J.: Tree stand volume as a scalar for methane fluxes in forestry-drained peatlands in Finland, Boreal Environ. Res., 12, 127-132, 2007.

Natchimuthu, S., Wallin, M. B., Klemedtsson, L., and Bastviken, D.: Spatio-temporal patterns of stream methane and carbon dioxide emissions in a hemiboreal catchment in Southwest Swe- den, Sci. Rep.-UK, 7, 39729, https://doi.org/10.1038/srep39729, 2017.

Nieminen, M., Koskinen, M., Sarkkola, S., Laurén, A., Kaila, A., Kiikkilä, O., Nieminen, T. M., and Ukonmaanaho, L.: Dissolved organic carbon export from harvested peatland forests with differing site characteristics, Water Air Soil Poll., 225, 181, https://doi.org/10.1007/s11270-015-2444-0, 2015.

Oertel, C., Matschullat, J., Zurba, K., Zimmermann, F., and Erasmi, S.: Greenhouse gas emissions from soils - A review, Geochemistry, 76, 327-352, https://doi.org/10.1016/j.chemer.2016.04.002, 2016.

Ojanen, P., Minkkinen, K., Alm, J., and Penttilä, T.: Soil atmosphere $\mathrm{CO}_{2}, \mathrm{CH}_{4}$ and $\mathrm{N}_{2} \mathrm{O}$ fluxes in boreal forestrydrained peatlands, Forest Ecol. Manag., 260, 411-421, https://doi.org/10.1016/j.foreco.2010.04.036, 2010.

Ojanen, P., Minkkinen, K., and Penttilä, T.: The current greenhouse gas impact of forestry-drained boreal peatlands, Forest Ecol. Manag., 289, 201-208, https://doi.org/10.1016/j.foreco.2012.10.008, 2013.

Ojanen, P., Lehtonen, A., Heikkinen, J., Penttilä, T., and Minkkinen, K.: Soil $\mathrm{CO}_{2}$ balance and its uncertainty in forestrydrained peatlands in Finland, Forest Ecol. Manag., 325, 60-73, https://doi.org/10.1016/j.foreco.2014.03.049, 2014.

Ojanen, P., Minkkinen, K., Alm, J., and Penttilä, T.: Corrigendum to "Soil-atmosphere $\mathrm{CO}_{2}, \mathrm{CH}_{4}$ and $\mathrm{N}_{2} \mathrm{O}$ fluxes in boreal forestry-drained peatlands" [For. Ecol. Manage., 260, 411-421, 2010], Forest Ecol. Manag., 412, 95-96, https://doi.org/10.1016/j.foreco.2018.01.020, 2018.

Päivänen, J.: The bulk density of peat and its determination, Silva Fenn., 3, 1-19, https://doi.org/10.14214/sf.a14569, 1969.

Papen, H. and Butterbach-Bahl, K.: A 3-year continuous record of nitrogen trace gas fluxes from untreated and limed soil of a $\mathrm{N}$-saturated spruce and beech forest ecosystem in Germany: 1. $\mathrm{N}_{2} \mathrm{O}$ emissions, J. Geophys. Res., 1041, 18487-18504, https://doi.org/10.1029/1999JD900293, 1999.

Pärn, J., Verhoeven, J., Butterbach-Bahl K., Dise, N., Ullah, S., Aasa, A., Egorov, S., Espenberg, M., Järveoja, J., Jauhiainen, J., Kasak, K., Klemedtsson, L., Kull, A., Laggoun-Défarge, F., Lapshina, E., Lohila, A., Lõhmus, K., Maddison, M., Mitsch, W., Müller, C., Niinemets, Ü., Osborne, B., Pae, T., Salm, J.-O., Sgouridis, F., Sohar, K., Soosaar, K., Storey, K., Teemusk, A., Tenywa, M., Tournebize, J., Truu, J., Veber, G., Villa, J., Zaw, S., and Mander, Ü.: Nitrogen-rich organic soils under warm welldrained conditions are global nitrous oxide emission hotspots, Nat. Commun., 9, 1135, https://doi.org/10.1038/s41467-01803540-1, 2018.

Pavelka, M., Acosta, M., Kiese, R., Altimir, N., Brümmer, C., Crill, P., Darenova, E., Fuß, R., Gielen, B., Graf, A., Klemedtsson, L., Lohila, A., Longdoz, B., Lindroth, A., Nilsson, M., Jiménez, S. M., Merbold, L., Montagnani, L., Peichl, M., Pihlatie, M., Pumpanen, J., Ortiz, P. S., Silvennoinen, H., Skiba, U., Vestin, P., Weslien, P., Janous, D., and Kutsch, W.: Standardisation of chamber technique for $\mathrm{CO}_{2}, \mathrm{~N}_{2} \mathrm{O}$ and $\mathrm{CH}_{4}$ fluxes measurements from terrestrial ecosystems, Int. Agrophys., 32, 569-587, https://doi.org/10.1515/intag-2017-0045, 2018.

Peacock, M., Ridley, L. M., Evans, C. D., and Gauci, V.: Management effects on greenhouse gas dynamics in fen ditches, Sci. Total Environ., 578, 601-612, https://doi.org/10.1016/j.scitotenv.2016.11.005, 2017. 
Petrescu, A. M. R., Lohila, A., Tuovinen, J.-P., Baldocchi, D. D., Desai, A. R., Roulet, N., Vesala T., Dolman, A. J., Oechel, W. C., Marcolla, B., Friborg, T., Rinne, J., Matthes J. C., Merbold, L., Meijide, A., Kiely, G., Sottocornola, M., Sachs, T., Zona, D., Varlagin, A., Lair, D. Y. F, Veenendaal, E., Parmentier, F .-J. W., Skiba, U., Lund, M., Hensen, A., van Huissteden, J., Flanagan, L. B., Shurpali, N. J., Grünwald, T., Humphreys, E. R., JackowiczKorczynski, M., Aurela, M. A, Laurila, T., Grüning, C., Corradi, C. A. R., Schrier-Uijls, A. P., Christensen, T. R., Tamstorf, M. P., Mastepanov, M., Martikainen, P. J., Verma, S. B., Bernhofer, C., and Cescatti, A.: The uncertain climate footprint of wetlands under human pressure, P. Natl. Acad. Sci. USA, 112, 4594-4599, https://doi.org/10.1073/pnas.1416267112, 2015.

Pitkänen, A., Turunen, J., Tahvanainen, T., and Simola, H.: Carbon storage change in a partially forestry-drained boreal mire determined through peat column inventories, Boreal Environ. Res., 18, 223-234, 2013.

Post, W. M., Emanuel, W. R., Zinke, P. J., and Stangenberger, A. G.: Soil carbon pools and world life zones, Nature, 298, 156159, https://doi.org/10.1038/298156a0, 1982.

Post, W. M., Pastor, J., Zinke, P. J., and Stangenberger, A. G.: Global patterns of soil nitrogen storage, Nature, 317, 613-616, https://doi.org/10.1038/317613a0, 1985.

Raghoebarsing, A. A., Smolders, A. J. P., Schmid, M. C., Rijpstra, W. I. C., Wolters-Arts, M., Derksen, J., Jetten, M. S. M., Schouten, S., Damsté, J. S. S., Lamers, L. P. M., Roelofs, J. G. M., Op den Camp, H. J. M., and Strous, M.: Methanotrophic symbionts provide carbon for photosynthesis in peat bogs, Nature, 436, 1153-1156, https://doi.org/10.1038/nature03802, 2005.

Repola, J.: Biomass equations for birch in Finland, Silva Fenn., 42, 605-624, https://doi.org/10.14214/sf.236, 2008.

Repola, J.: Biomass equations for Scots pine and Norway spruce in Finland, Silva Fenn., 43, 625-647, https://doi.org/10.14214/sf.184, 2009.

Roulet, N. T. and Moore, T. R.: The effect of forestry drainage practices on the emission of methane from northern peatlands, Can. J. Forest Res., 25, 491-499, https://doi.org/10.1139/x95-055, 1995.

Rusch, H. and Rennenberg, H.: Black alder (Alnus Glutinosa (L.) Gaertn.) trees mediate methane and nitrous oxide emission from the soil to the atmosphere, Plant Soil, 201, 1-7, https://doi.org/10.1023/A:1004331521059, 1998.

Saarinen, M. and Hotanen, J.-P.: Covariation between raw humus layer and vegetation on peatlands drained for forestry in western Finland, Suo, 51, 227-242, 2000 (in Finnish, summary and graphics in English).

Saarnio, S. and Silvola, J.: Effects of increased $\mathrm{CO}_{2}$ and $\mathrm{N}$ on $\mathrm{CH}_{4}$ efflux from a boreal mire: a growth chamber experiment, Oecologia, 119, 349-356, https://doi.org/10.1007/s004420050795, 1999.

Sander, B. O. and Wassmann, R.: Common practices for manual greenhouse gas sampling in rice production: a literature study on sampling modalities of the closed chamber method, Greenhouse Gas Measurement and Management, 4, 1-13, https://doi.org/10.1080/20430779.2014.892807, 2014.

Sarkkola, S., Hökkä, H., Koivusalo, H., Nieminen, M., Ahti, E., Päivänen, J., and Laine, J.: Role of tree stand evapotranspiration in maintaining satisfactory drainage conditions in drained peatlands, Can. J. Forest Res., 40, 1485-1496, https://doi.org/10.1139/X10-084, 2010.

Silc, T. and Stanek, W.: Bulk density estimation of several peats in northern Ontario using the von Post humification scale, Can. J. Soil Sci., 51, 138-141, https://doi.org/10.4141/cjss77-010, 1977.

Simola, H., Pitkänen, A., and Turunen, J.: Carbon loss in drained forestry peatlands in Finland, estimated by re-sampling peatlands surveyed in the 1980s, Eur. J. Soil Sci., 63, 798-807, https://doi.org/10.1111/j.1365-2389.2012.01499.x, 2012.

Sirin, A. A., Suvorov, G. G., Chistotin, M. V., and Glagolev, M. V.: Values of methane emission from drainage ditches. Environmental Dynamics and Climate Change, 3, 1-10, https://doi.org/10.17816/edgcc321-10, 2012.

Statistics Finland: Greenhouse gas emissions in Finland 1990 to 2017, National Inventory Report under the UNFCCC and the Kyoto protocol, European Union, Statistics Finland, available at: https://unfccc.int/documents/194637 (last acccess: 4 December 2019), 2019.

Strack, M., Waller, M. F., and Waddington, J. M.: Sedge succession and peatland methane dynamics: A potential feedback to climate change, Ecosystems, 9, 278-287, https://doi.org/10.1007/s10021-005-0070-1, 2006.

Strack, M., Waddington, J. M., Bourbonniere, R. A., Buckton, L., Shaw, K., Whittington, P., and Price, J. S.: Effect of water table drawdown on peatland dissolved organic carbon export and dynamics, Hydrol. Process., 22, 3373-3385, https://doi.org/10.1002/hyp.6931, 2008.

Straková, P., Anttila, J., Spetz, P., Kitunen, V., Tapanila, T., and Laiho, R.: Litter quality and its response to water level drawdown in boreal peatlands at plant species and community level, Plant Soil, 335, 501-520, https://doi.org/10.1007/s11104-010-0447-6, 2010.

Straková, P., Niemi, R. M., Freeman, C., Peltoniemi, K., Toberman, H., Heiskanen, I., Fritze, H., and Laiho, R.: Litter type affects the activity of aerobic decomposers in a boreal peatland more than site nutrient and water table regimes, Biogeosciences, 8, 27412755, https://doi.org/10.5194/bg-8-2741-2011, 2011.

Straková, P., Penttilä, T., Laine, J., and Laiho, R.: Disentangling direct and indirect effects of water table drawdown on above- and belowground plant litter decomposition: Consequences for accumulation of organic matter in boreal peatlands, Glob. Change Biol., 18, 322-335, https://doi.org/10.1111/j.13652486.2011.02503.x, 2012.

Subke, J.-A., Inglima, I., and Cotrufo, M. F.: Trends and methodological impacts in soil $\mathrm{CO}_{2}$ efflux partitioning: A meta-analytical review, Glob. Change Biol., 12, 921-943, https://doi.org/10.1111/j.1365-2486.2006.01117.x, 2006.

Tubiello, F. N., Biancalani, R., Salvatore, M., Rossi, S., and Conchedda, G.: A Worldwide assessment of greenhouse gas emissions from drained organic soils, Sustainability, 8, 371, https://doi.org/10.3390/su8040371, 2016.

Tuomi, M., Laiho, R., Repo, A., and Liski, J.: Wood decomposition model for boreal forests, Ecol. Model., 222, 709-718, https://doi.org/10.1016/j.ecolmodel.2010.10.025, 2010.

Ťupek, B., Mäkipää, R., Heikkinen, J., Peltoniemi, M., Ukonmaanaho, L., Hokkanen, T., Nöjd, P., Nevalainen, S., Lindgren, M., and Lehtonen, A.: Foliar turnover rates in Finland - comparing estimates from needle-cohort and litterfall-biomass methods, Boreal Environ. Res., 20, 283-304, 2015. 
Urbanová, Z., Picek, T., and Bárta, J.: Effect of peat re-wetting on carbon and nutrient fluxes, greenhouse gas production and diversity of methanogenic archaeal community, Ecol. Eng., 37, 10171026, https://doi.org/10.1016/j.ecoleng.2010.07.012, 2011.

Uri, V., Kukumägi, M., Aosaar, J., Varik, M., Becker, H., Morozov, G., and Karoles, K.: Ecosystems carbon budgets of differently aged downy birch stands growing on well-drained peatlands, Forest Ecol. Manag., 399, 82-93, https://doi.org/10.1016/j.foreco.2017.05.023, 2017.

von Arnold, K., Nilsson, M., Hånell, B., Weslien, P., and Klemedtsson, $\mathrm{L}$.: Fluxes of $\mathrm{CO}_{2}, \mathrm{CH}_{4}$ and $\mathrm{N}_{2} \mathrm{O}$ from drained organic soils in deciduous forests, Soil Biol. Biochem., 37, 1059-1071, https://doi.org/10.1016/j.soilbio.2004.11.004, 2005a.

von Arnold, K., Weslien, P., Nilsson, M., Svensson, B. H., and Klemedtsson, L.: Fluxes of $\mathrm{CO}_{2}, \mathrm{CH}_{4}$ and $\mathrm{N}_{2} \mathrm{O}$ from drained coniferous forests on organic soils, Forest Ecol. Manag., 210, 239-254, https://doi.org/10.1016/j.foreco.2005.02.031, 2005b.

Wang, X., Wang, C., and Bond-Lamberty, B.: Quantifying and reducing the differences in forest $\mathrm{CO}_{2}$-fluxes estimated by eddy covariance, biometric and chamber methods: A global synthesis, Agr. Forest Meteorol., 247, 93-103, https://doi.org/10.1016/j.agrformet.2017.07.023, 2017.
Weiss, R., Alm, J., Laiho, R., and Laine, J.: Modelling moisture retention in peat soils, Soil Sci. Soc. Am. J., 62, 305-313, https://doi.org/10.2136/sssaj1998.03615995006200020002x, 1998.

Welch, B., Gauci, V., and Sayer, E. J.: Tree stem bases are sources of $\mathrm{CH}_{4}$ and $\mathrm{N}_{2} \mathrm{O}$ in a tropical forest on upland soil during the dry to wet season transition, Glob. Change Biol., 25, 361-372, https://doi.org/10.1111/gcb.14498, 2019.

Wilson, D., Blain, D., Couwenberg, J., Evans, C. D., Murdiyarso, D., Page, S. E., Renou-Wilson, F., Rieley, J. O., Sirin, A., Strack, M., and Tuittila, E.-S.: Greenhouse gas emission factors associated with rewetting of organic soils, Mires Peat, 17, 1-28, https://doi.org/10.19189/MaP.2016.OMB.222, 2016. 